\title{
Life satisfaction in Brazil: an exploration of theoretical correlates and age, period and cohort variations using the World Values Survey (1991-2014)*
}

\author{
André Golgher ${ }^{\star \star}$ \\ Raquel Zanatta Coutinho ${ }^{\star \star \star}$
}

\begin{abstract}
This paper discusses some of the factors associated with life satisfaction in Brazil using four waves of the World Values Survey (1991 to 2014). Some results already described in the literature were confirmed, as we found that individuals who were married, employed, more religious, in better health, with greater freedom/control over their lives and who had a better financial situation were more satisfied with life, regardless of the time period. The variables for age and cohort showed non-significant associations with life satisfaction when aspects that theoretically correlated with life satisfaction were controlled in the analysis. When the different cohorts were analyzed separately, the results suggest that life satisfaction might be related to the conjectural and historical factors represented by period effects.
\end{abstract}

Keywords: Life satisfaction. Brazil. World Values Survey.

\footnotetext{
* Raquel Zanatta Coutinho thanks the support of UFMG - Universidade Federal de Minas Gerais (Federal University of Minas Gerais), Edital 11/2017 - ADRC, Institutional Research Assistance Program for Recently Hired Professors and New PhDs at UFMG. André Braz Golgher thanks the support of CNPq (National Research Council), PQ Fellowship.

${ }^{\star \star}$ Centro de Desenvolvimento e Planejamento Regional (Cedeplar), Universidade Federal de Minas Gerais (UFMG), Belo Horizonte-MG, Brazil (agolgher@gmail.com; 0000-0001-5884-225X).

${ }^{\star \star \star}$ Centro de Desenvolvimento e Planejamento Regional (Cedeplar), Universidade Federal de Minas Gerais (UFMG), Belo Horizonte-MG, Brazil (quelzanatta@cedeplar.ufmg.br; 0000-0002-2841-1480).
} 


\section{Introduction}

The field of Happiness Economics has grown remarkably since Richard A. Easterlin (1974) wrote his influential paper. In this seminal work, the author demonstrates how different levels of happiness are correlated with different levels of income both among and within countries at any given time, but that over time happiness does not trend upward at the same pace as economic growth. This came to be known as the "Easterlin Paradox." The subject is now an extensive field of inquiry among economists and social scientists. A large set of new methods and theories were developed, and many noteworthy studies were published, in an attempt to uncover what else, apart from income, is the main driver of a happy life (BLANCHFLOWER; OSWALD, 2004; DOLAN et al., 2008; FOSSE; WINSHIP, 2019; GRAHAM; CHATTOPADHYAY, 2013; GRAHAM; CROWN, 2014; KAHNEMAN et al., 2006). Reviewing the literature, Dolan et al. (2008, p. 97) identifies six other factors, besides income (1) which are commonly associated with life satisfaction: they are (2) personal characteristics; (3) socially developed characteristics; (4) individuals' predominant ways of spending time; (5) attitudes and beliefs towards self/others/life; (6) relationships; and (7) the wider economic, social and political environment.

In the case of Brazil, studies have endorsed many of the findings shown by the international evidence (CORBI; MENEZES-FILHO, 2006; ISLAM et al., 2009; RIBEIRO, 2015; RIBEIRO; MARINHO, 2017; GOLGHER, 2014a, 2014b, 2014c). Other studies compared Brazil with other countries (CAVALCANTI et al., 2009; ONUSIC; MENDES-DA-SILVA, 2015) or included Brazil in a broader context (GRAHAM; PETTINATO, 2001; GRAHAM et al., 2011). Thus, the topic discussed in this paper has already been addressed by different methodologies and approaches.

However, as happiness levels might fluctuate, when analyzing levels of happiness over time, researchers must take into account birth cohort, age, and historical period (YANG, 2008; FUKUDA, 2013). This paper proposes to fill a gap in the Brazilian literature by combining an analysis of happiness levels over time including age, period, and cohort (APC) as explanatory variables. Previous studies have used similar methodology in other fields of inquiry (for a discussion about the labor market, see Leme and Wajnman (2000); for religion, see Coutinho and Golgher (2014); for education, see Guimarães and Rios-Neto (2011); and for health, see Souza et al. (2012).

More specifically, this paper discusses the factors associated with life satisfaction in Brazil for people between 18 and 72 years of age, using four waves of the World Values Survey (WVS) from 1991 to 2014. The WVS directly addresses well-being with two variables, one associated with happiness and another with life satisfaction, as in many other datasets (JORM; RYAN, 2014). Happiness, life satisfaction and well-being differ in essence and significance (HALLER; HADLER, 2006; MEDVEDEV; LANDHUIS, 2018; $N G, 2015)$. Following Ng (2015), happiness can be defined as a global evaluation of the individual's life quality according to cognitive or emotional aspects (MEDVEDEV; LANDHUIS, 
2018; NEMATI; MARALANI, 2016). It is greatly determined by positive and close social relationships, purpose in life, personal growth, environmental mastery, autonomy, and positive self-esteem (HALLER; HADLER, 2006; MEDVEDEV; LANDHUIS, 2018; NEMATI; MARALANI, 2016). Life satisfaction is a measure characterized by comparisons between an individual's wishes and the present state of that individual's life. Hence, it is likely to be more affected by the objective/material conditions of life and by the perceived discrepancy between aspirations or expectations and actual achievements. Thus, shifts in aspiration level influence this indicator more than they affect happiness (MEDVEDEV; LANDHUIS, 2018; NEMATI; MARALANI, 2016; NG, 2015).

However, variables related to happiness and to life satisfaction tend to be strongly and positively correlated (HALLER; HADLER, 2006; MEDVEDEV; LANDHUIS, 2018). Besides, the applied definitions for these variables indicate conceptual overlap between them (MEDVEDEV; LANDHUIS, 2018). Moreover, in general, the determinants of both are quite similar (HELLIWELL; LAYARD; SACHS, 2016). The most common procedure is to use only one of these variables. This paper follows that procedure, choosing to analyze life satisfaction.

We initially describe the APC effects graphically and then relate these effects to the possible impacts of some of the main factors that correlate with life satisfaction. Then we use regression models estimated by Ordinal Least Square controlling for age, period and cohort, and also for theoretical correlates of life satisfaction.

It should be emphasized that we analyze correlations in this paper, and correlations cannot be considered causal relations. The paper uses a cross-sectional dataset and the empirical design is not one of an experimental or quasi-experimental nature (ANGRIST; PISCHKE, 2009).

Apart from this introduction, the paper is structured as follows: The second section presents a review of the literature. The third section describes the methodology, which includes the dataset, APC approach, synthetic cohorts, variables, and econometric models. The fourth section presents the results based on descriptive statistics and founded on the econometric models. The last section contains the conclusions of the paper.

\section{Literature review}

This section describes some of the main factors that correlate with happiness, life satisfaction, and well-being. As mentioned above, happiness, life satisfaction, and wellbeing differ in essence and significance (HALLER; HADLER, 2006; MEDVEDEV; LANDHUIS, 2018; NG, 2015). Life satisfaction was the variable chosen for the empirical analysis in this paper. Nonetheless, these three variables tend to show similar correlations with explanatory variables (HALLER; HADLER, 2006; HELLIWELL; LAYARD; SACHS, 2016; MEDVEDEV; LANDHUIS, 2018). Therefore, in this section we present different studies that addressed the three concepts. The term well-being is used here as a general concept encompassing 
happiness and life satisfaction, as definitions for these variables indicate conceptual overlap between them (MEDVEDEV; LANDHUIS, 2018).

Among the variables associated with personal characteristics, age, gender, and race are commonly included in studies that analyze the factors that correlate with happiness, life satisfaction and well-being. However, in general, results are not conclusive for the first the two (LAYARD, 2005).

Blanchflower and Oswald (2004) found an inverse U-shaped relation between wellbeing and age for the US and a U-shaped relation for Britain. Graham (2008) observed a U-shaped relation for the US and for Latin America. For Brazil, Ribeiro (2015) found a positive correlation between age and well-being, while Corbi and Menezes-Filho (2006) found non-significant results for this association.

For gender, Graham and Chattopadhyay (2013) found that women had higher levels of well-being than men in most countries, and Blanchflower and Oswald (2004) observed the same for the USA and for Britain. For Brazilian data, some studies found that gender was non-significant for happiness and for life satisfaction (CORBI; MENEZES-FILHO, 2006; GOLGHER, 2014a) while others found that men were happier (GOLGHER, 2014a).

Race is also commonly included in studies that analyze the factors that correlate with well-being. For the US, Blanchflower and Oswald (2004) and Graham (2008) observed that Whites were happier than Blacks. For Brazilian data, Golgher (2014a, 2014b) found that Whites were happier than non-Whites, but were less satisfied with life, indicating the sensitivity of the results depending on the dependent variable.

Socially developed characteristics frequently include health status, employment status, educational attainment, and income (BLANCHFLOWER; OSWALD, 2004; DOLAN et al., 2008; GRAHAM et al., 2011; KAHNEMAN et al., 2006). Studies constantly show a solid positive relationship between happiness or life satisfaction and both physical and psychological health (DOLAN et al., 2008). In the same vein, Graham et al. (2011), Haller and Hadler (2006) and Helliwell (2006) observed that well-being and health tend to be positively correlated. Ribeiro (2015) and Golgher (2014a) analyzed Brazilian data and came to the same conclusion. Notice that circular causality might exist, as healthier people tend to be happier and happier people tend to be healthier; however, the causality is most likely to go in the direction of people reporting higher levels of well-being when they are in better health (DOLAN et al., 2008).

Studies consistently show large negative effects of unemployment on well-being (BLANCHFLOWER; OSWALD, 2004; DOLAN et al., 2008; GRAHAM, 2008; HALLER; HADLER, 2006; HELLIWELL; PUTNAM, 2004). The same result was also found with Brazilian data (CORBI; MENEZES-FILHO, 2006; GOLGHER, 2014a). Unemployed individuals suffer from loss of income, but this is only part of the impact, as unemployment causes depression, anxiety, and social isolation as well as loss of self-esteem and personal control (LAYARD, 2005). Winkelmann and Winkelmann (1998) showed that non-pecuniary effects of unemployment might be much more relevant than the loss of income. Nevertheless, there is also the 
possibility of reverse causality: unhappy individuals tend to be less productive and might show a greater propensity to become unemployed.

Blanchflower and Oswald (2004) and Kahneman et al. (2006) observed that individuals who were more educated were happier. Similarly, Oreopoulos (2007) verified not only that individuals with higher educational attainment were more likely to report being satisfied with the lives they had, but also that they were less likely to report poor health, depression or unemployment, suggesting indirect effects of formal education on well-being levels. Layard (2005) stated that the direct effects of education might be small, although the indirect effects, due to income increase and others, might be noticeable. Along these lines, Graham (2008) showed non-significant coefficients for education when a set of controls were included in the analysis. For Brazilian data, most results associating education and well-being were non-significant (CORBI; MENEZES-FILHO, 2006; GOLGHER, 2014a; RIBEIRO, 2015).

Regarding income, Blanchflower and Oswald (2004) and Graham (2008) verified that richer individuals tended to be happier. Islam et al. (2009) and Ribeiro (2015) arrived at the same conclusion for Brazilian data. Frey (2008) and Kahneman et al. (2006) stated that income is positively associated with happiness, but only slightly, and only up to a certain income level. Income tends to be weakly or non-significantly correlated with well-being in many settings (SHIELDS; PRICE, 2005). Nevertheless, income might not correspond closely to perceived income; in other words, having a certain income might not indicate precisely how individuals judge their financial situation or wealth in relation to others. Therefore, perceptions of financial status might have a stronger predictive power than actual income, as verified by different authors (DOLAN et al., 2008; GRAHAM; PETTINATO, 2001; HALLER; HADLER, 2006; JOHNSON; KRUEGER, 2006), and empirically observed for Brazilian data (GOLGHER, 2014, 2014b, 2014c; RIBEIRO, 2015).

Marital status is among the most important features that impact individual well-being. In general, married people tend to be happier (BLANCHFLOWER; OSWALD, 2004; DOLAN et al., 2008; GRAHAM, 2008; HALLER; HADLER, 2006; HELLIWELL, 2006; SLUTZER; FREY, 2006), and this has also been shown in Brazil (CORBI; MENEZES-FILHO, 2006; RIBEIRO, 2015). Married people tend to be wealthier and healthier, and tend to have a "natural" protective net for adverse life events (FREY, 2008). However, another explanation is due to reverse causality: married people are happier because happier people have a greater propensity to get married and/or not to divorce (SLUTZER; FREY, 2006). Besides, individuals who give more importance to family tend to have higher levels of well-being in Brazil (GOLGHER, 2014b).

Higher levels of religiosity might positively affect well-being for different reasons (GRAHAM; CROWN, 2014; HALLER; HADLER, 2006), irrespective of the chosen religion (DOLAN et al., 2008). Dolan et al. (2008), Haller and Hadler (2006), Helliwell (2006), and Graham and Crown (2014) emphasized that individuals who give more importance to God and/or to religion and who attend religious services often tend to be happier. They stated that religion has many channels that might enhance well-being, such as social externalities, 
psychological insurance, and the intrinsic belief and purpose of religiosity. Besides, religious individuals also tend to be healthier and have better safety nets to protect them against unemployment, separation, or divorce (CLARK; LELKES, 2005). Golgher (2014b) and Ribeiro (2015) observed that religiosity was also positively correlated with well-being in Brazil.

Well-being is also strongly correlated with other features associated with attitudes and beliefs, such as self-determination (DOLAN et al., 2008; GRAHAM; CROWN, 2014; PUTNAM, 2000). Haller and Hadler (2006) and Johnson and Krueger (2006) verified a positive correlation between perceived control over life and life satisfaction. This same relationship was observed empirically with Brazilian data (GOLGHER, 2014b, 2014c; RIBEIRO, 2015).

All these variables are among the theoretical correlates with well-being levels. However, as happiness levels might fluctuate when analyzing levels of happiness over time, it is important to take into account birth cohort, age, and historical period (YANG, 2008; FUKUDA, 2013).

When changes take place in a specific age group (or groups) most strongly, the result is an age effect - that is, aging-related developmental changes that occur over the course of a lifetime. In this case, one would observe that certain age groups, regardless of their cohort or period, share the same characteristics or face the same phenomena. An example of this could be the probability of older people being more satisfied with life than youngsters irrespective of cohort or period, since they could simply be more thankful to still be alive, having outlived some of their counterparts. When changes occur in all age groups at the same time, this creates a period effect, which reflects changes in social, historical and epidemiological conditions unique to a time period that affect all living conditions regardless of age or life stage (YANG, 2011, p. 18). Economic shocks are examples of period effects likely to affect the society in which they occur as a whole. Finally, cohort effects refer to individuals who share specific experiences, such as being born in the same year or entering a university in the same period. According to Ryder (1965), birth cohorts represent the effect of formative experience, shaped not only by life conditions from the moment of birth but also by a continuous and shared exposure to historical and social factors that might affect living conditions throughout life, thus making the specific group unique. For instance, individuals of specific cohorts might trust others less than other cohorts, independently of age or period effects, and these differences could ultimately affect their levels of happiness.

Yang (2008) addressed the differences in subjective well-being in the US using the APC approach. She found a positive association between age and happiness over the course of a lifetime. For period effects, the author first observed decreasing and then increasing trends in happiness. She concluded that baby boomer cohorts had lower levels of happiness, indicating the influence of early life conditions. However, results for period, as well as for cohorts, may be very sensitive to the context being studied.

Box 1 presents a summary of the main findings discussed in this section. 
BOX 1

Main conclusion regarding the factors that correlate with well-being

\begin{tabular}{|lll|}
\hline Variable & Overall conclusions & Conclusions with Brazilian data \\
\hline Age & $\begin{array}{l}\text { Not conclusive/ } \\
\text { Positive/ } \\
\text { Inverse U-shaped/ } \\
\text { Mostly U-shaped }\end{array}$ & Non-significant/positive \\
\hline Period & Context-dependent & - \\
\hline Cohort & Context-dependent & Non-significant/ Men had higher levels \\
\hline Gender & $\begin{array}{l}\text { Not conclusive/Women mostly had well-being } \\
\text { higher levels of well-being }\end{array}$ \\
\hline Race & Whites had higher levels of well-being. & $\begin{array}{l}\text { Whites mostly had higher levels of well- } \\
\text { being/In some settings, Non-Whites } \\
\text { had higher levels of well-being. }\end{array}$ \\
\hline Health status & Healthier individuals had higher levels of well-being. \\
\hline Unemployment & \begin{tabular}{l} 
Unemployed individuals had lower levels of well-being. \\
\hline Education
\end{tabular} & $\begin{array}{l}\text { The higher the education level, the } \\
\text { higher the well-being level; however, } \\
\text { direct effects might be small. }\end{array}$ \\
\hline Income/ Financial situation results were mostly non-significant. \\
\hline Marital status & Richer individuals had higher levels of well-being. \\
\hline Religiosity & Married individuals had higher levels of well-being. \\
\hline Self-determination & More religious individuals tended to have higher levels of well-being. \\
\hline
\end{tabular}

Most of the above-mentioned studies addressed correlations between well-being and a myriad of factors. Correlations cannot be considered causal relations, although they can be highly suggestive of causality in some settings and methodologies (ANGRIST; PISCHKE, 2009). Moreover, as mentioned above, circular causality may occur between different factors and well-being. For instance, happier individuals may be more productive, consequently earning higher wages and being less prone to unemployment. The use of longitudinal datasets may disentangle the effects of circular causality. For instance, Veehoven (2008) described many studies that analyzed associations between health and happiness. Unfortunately, the WVS dataset is not longitudinal; nevertheless, in order to overcome some of the limitations of cross-sectional data, we created synthetic cohorts.

This section presented some of the factors that correlate with well-being. We applied some of them in our empirical analysis of the factors associated with life satisfaction in Brazil, while also using age, period and cohort as explanatory variables, as well as several other variables available in the WVS. The methodology is described in detail in the next section.

\section{Methodological section}

\section{Dataset}

The World Values Surveys are representative national surveys which have been carried out in approximately 100 societies since 1981 . These surveys contain basic demographic data such as age, gender, and marital status for individuals aged 18 and over. Moreover, 
they research what people want from life, what they believe, and how they evaluate their lives (see http://www.worldvaluessurvey.org/ for further details). This type of questionnaire enables researchers to explore the direct links between values, opinions and self-evaluated well-being levels and a myriad of explanatory variables. Specifically for Brazil, there are four survey waves, collected in the years 1991, 1997, 2006 and 2014, with 1,782, 1,149, 1,500 and 1,486 observations respectively. We used the four waves in our empirical analysis.

\section{Age-period-cohort concepts}

This paper describes the factors associated with life satisfaction using age, period and cohort as a subset of the explanatory variables (YANG, 2008; FUKUDA, 2013). However, age, period and cohort have confounding aspects if used together in the same regression (YANG et al., 2004). That happens because, by knowing a person's age and the year of the interview, it is possible to learn their cohort. Because of the linear dependency among these three variables, models using the APC approach present problems of identification (BELL; JONES, 2013; GLENN, 2003; KUPPER et al., 1985). Fosse and Winship (2019), Smith (2004), Yang et al. (2004), and Yang et al. (2008) listed several methods that can be used to minimize these problems, such as equality constraints, the Intrinsic Estimator (IE), and the Hierarchical APC (HAPC) model. Although many approaches have been proposed to solve the APC conundrum, as emphasized by Bell and Jones (2013), most or all types of modeling are unable to solve the identification problem adequately, all of them have limitations, and no consensus has been established.

In addition, this type of analysis may not provide adequate interpretation advantages over traditional graphic methods (KUPPER et al., 1985) or for causal inferences (SMITH, 2004). Critics of the APC approach consider it ad hoc and atheoretical, and the interactions of the model may make it difficult to capture the real atmosphere of a period. On the other hand, authors argue that the technique can be a useful tool for empirical analysis (SMITH, 2004), and that it can even provide causal structures if proper assumptions based on theory are made (FOSSE; WINSHIP, 2019). Following these last authors, age, period and cohort may indicate other real factors that cause the observed variation in the variable of interest. For instance, O'Brien and Stockard (2009) partially explained cohort effects including cohort size and the percentage of non-marital births while discussing homicide rates. Thus, it is still possible to overcome the limitations of age-period-cohort linear dependency if an appropriate set of factors can control the linear variation of one of these three variables (FOSSE; WINSHIP, 2019).

For this paper in particular, in order to overcome some of these difficulties, we used as explanatory variables age and age squared, a nonlinear association of age with life satisfaction. Moreover, we built synthetic cohorts, as described in the next subsection, a common procedure (BELL; JONES, 2013). By grouping individuals of different ages in the same cohort, we break the linear dependency mentioned above (YANG, 2008). Moreover, this paper takes the approach recommended by Bell and Jones (2013), assuming that 
period effects are not continuous. This assumption enables the robust modeling of age and cohort effects, which is the approach taken on this paper. Besides, as proposed by Fosse and Winship (2019), the use of explanatory variables representing part of the variation of age, period or cohort may decrease linear variations in one of these variables. Nonetheless, the methodology still presents some of the limitations of the APC approach due to the identification problem, which has not yet been reasonably resolved.

\section{Synthetic cohorts}

The models proposed in the present analysis are not pseudo-panel. We built the synthetic cohorts in order to obtain a categorical variable as explanatory in models that use individual data. The use of synthetic cohorts is now a well-established methodology (DEATON, 1985; VERBEEK; NIJMAN, 1992; DEVEREUX, 2007), and it is widely used in many settings.

The most commonly used procedure to build cohorts is to make groups in fixed interval lengths, such as five years. However, the WVS dataset's samples are reasonably small. Besides, while the minimum age of respondents is 18 , given that the number of observations of older groups is smaller, a different procedure to build synthetic cohorts and use them as explanatory variables in our models was required.

Individuals were classified according to their year of birth, 1942-1951, 1952-1961, 1962-1967 and 1968-1973, in all four WVS waves. The youngest cohort was aged 18 to 23 in 1991 and the oldest was aged 63 to 72 in 2014 . Although we do not have the same individuals in the four waves, we assume that these groups represent similar groups of individuals in the population in the four waves. All cohort-years had at least 140 observations with a mean value of more than 225, as proposed by Verbeek and Nijman (1992).

Notice that the three younger cohorts mimic their respective birth cohorts more, because the oldest cohort was aged 63 to 72 in 2014, and selective mortality may have occurred, as a reasonable number of individuals in this age range may have already passed away. Health and life satisfaction tend to be positively correlated. Thus mortality rates and life satisfaction are expected to be negatively correlated. Liu et al. (2016) observed that previous studies reported that mortality was negatively associated with happiness, possibly due to poor health and lifestyle factors that can affect happiness and mortality. They verified that after controlling for self-rated health, treatment for different diseases and several sociodemographic and lifestyle factors, unhappiness was not significantly associated with mortality. Hence, for the oldest cohort in this paper, the one aged 63 to 72 in 2014, although no direct causal effect between well-being and mortality can be claimed, due to indirect impacts, selective mortality may occur and life satisfaction levels tend to be higher than they might be without this selection.

Moreover, the WVS in 1991 set the age limit at 55 for all individuals aged 50 or more. Due to this limitation, we excluded these individuals from the analysis for the 1991 dataset. Data for the other years did not show this limitation. 


\section{Variables}

This paper discusses the factors associated with life satisfaction in Brazil using the APC variables. The WVS has many variables representing different aspects of life that could potentially affect life satisfaction level. However, some of them are not present in all four Brazilian waves. In order to be able to use all WVS waves, and consequently to obtain a larger sample, we only selected variables that were incorporated in all WVS waves. Moreover, the selected variables were clearly associated with life satisfaction levels in previous studies that addressed Brazilian data, as presented in the previous section, and they encompassed most realms in human life (DOLAN et al., 2008): socially developed characteristics (health status, employment status and educational attainment); income (financial situation); relationships (marital status); attitudes and beliefs towards self/others/life (religiosity and self-determination); and the wider economic, social and political environment (selfdetermination). Hence, the variables were selected according to data availability as well as empirical and theoretical relevance. We briefly present the dependent and independent variables in the following paragraphs. A description of the variables can be found in Box 2 .

Regarding happiness and life satisfaction, the WVS has a variable for each domain. In general, differences between the factors that correlate with these indicators are not remarkable (HELLIWELL; LAYARD; SACHS, 2016). Thus, for the sake of brevity, we selected the second one to be the dependent variable in the econometric models. Answers ranged from 1 , totally unsatisfied, to 10 , totally satisfied. However, the first four categories were not frequently selected and were aggregated. Thus, the dependent variable has seven categories. The variable is treated as continuous and the chosen model was a standard model estimated by OLS, as in Frey (2008).

Concerning the APC variables, we included age as a continuous variable, and due to possible nonlinearities we also included age squared. This is the most widely used procedure in studies that address the relationship between age and well-being (BLANCHFLOWER; OSWALD, 2004; CORBI; MENEZES-FILHO, 2006; GRAHAM, 2008; RIBEIRO, 2015). We also included a categorical variable for period with four categories (1991,1997, 2006 and 2014), as these are the four years of available data. In addition, we included another variable for synthetic cohort, also with four categories, according to the individual's year of birth (1942-1951, 1952-1961, 1962-1967 or 1968-1973). These age brackets were chosen to have the same cohorts in the four years of data availability and to have a reasonable number of observations in all years/cohorts. These were the chosen variables representing age, period and cohort in regressions with adjustments controlling for APC effects.

Many variables already introduced in the theoretical section are used as explanatory. Gender and racial group are represented by dummies, respectively ( 1 - male, 0 - female) and ( 1 - whites, 0 - non-whites). Health status is a categorical variable with three possible responses ( 0 - poor and fair health, 1 - good health, and 2 - very good health). Marital status is a categorical variable (1 - married, 2 - living together, 3 - divorced/separated, 
4 - widowed, 5 - single/never married). The importance given to family is a dummy (1 - very important; 0 - not important or only slightly important). The WVS for Brazil had the following categories for employment status: full-time workers, part-time workers, selfemployed people, retired people, homemakers, students, and unemployed people. We created a dummy indicating whether the individual was unemployed or not (1 - yes, 0 - no).

Household financial satisfaction is classified on a scale of ten from totally dissatisfied to totally satisfied. Notice that the measure is subjective. Hence, it is partly defined by comparison with other individuals, a feature that is also taken into account in the reporting of life satisfaction levels.

The categorical variable for education has five categories: 1 - incomplete elementary education; 2 - incomplete secondary school; 3 - complete secondary school; 4 - some university, without degree; and 5 - university, with degree.

In the WVS dataset there are some variables related to religion and religiosity, which were grouped due to their high collinearity. One index grouped questions related to the importance of religion, the importance of God, and whether or not the person considered him/herself to be religious. This index has four ordered categories, from less to more religious. Concerning freedom of choice and control over one's own life, the variable has seven categories, from less to more control, and was treated as continuous.

Box 2 summarizes the information about the variables. The labels are used in the following section, which presents the econometric model.

BOX 2

Variables

\begin{tabular}{|lll|}
\hline Variable & Label & Type \\
\hline Life satisfaction & Y & Continuous \\
\hline Age & Age & Continuous \\
\hline Periods & Periods & Categorical. Years: 1991, 1997, 2006 and 2014 \\
\hline Cohorts & Cohorts & $\begin{array}{l}\text { Categorical. Born in: 1942-1951, 1952-1961, 1962-1967 or 1968- } \\
\text { 1973 }\end{array}$ \\
\hline Sex & Male & Dummy \\
\hline Ethnic group & White & Dummy \\
\hline Health level & Health & Ordered: poor, good and very good \\
\hline Marital status & Marital & $\begin{array}{l}\text { Categorical: married, cohabiting, divorced/separated, widowed } \\
\text { and single }\end{array}$ \\
\hline $\begin{array}{lll}\text { Importance given to } \\
\text { family }\end{array}$ & Family & Dummy \\
\hline Financial situation & Finance & Continuous \\
\hline Employment status & Unemployed & Dummy \\
\hline Educational attainment & Education & $\begin{array}{l}\text { Ordered: incomplete elementary education; incomplete } \\
\text { secondary school; complete secondary school; some university } \\
\text { without degree; and university with degree. }\end{array}$ \\
\hline Religiosity & Religion & $\begin{array}{l}\text { Ordered: not religious, slightly religious, religious and very } \\
\text { religious }\end{array}$ \\
\hline Self-determination & Freedom & \begin{tabular}{l} 
Continuous \\
\hline
\end{tabular} \\
\hline
\end{tabular}




\section{Econometric models}

In our analysis, we applied standard linear models estimated by OLS. The equation below represents the general model we used:

$Y=\beta_{\mathrm{o}}+\beta_{1}$ Age $+\beta_{1}$ Age ${ }^{2}+\beta_{3-5}$ Periods $+\beta_{6-8}$ Cohorts $+\beta_{9}$ Male $+\beta_{10}$ White

$+\beta_{11-12}$ Health $+\beta_{13-16}$ Marital $+\beta_{17}$ Family $+\beta_{18}$ Unemployed $+\beta_{19-22}$ Education

$+\beta_{23}$ Finance $+\beta_{24}$ Religion $+\beta_{25}$ Freedom $+\varepsilon$

Where the variables have already been defined in Box 2.

First, we used Stata 13 to estimate OLS models with subsets of the explanatory variables and compared to a full model. The objective is to show the robustness of the results of the APC and the other explanatory variables. To improve model fit, we modeled each cohort separately. Ordered logistic models tend to show very similar results to OLS models in previous well-being studies with Brazilian data. Thus, it was considered that the variable could be treated as continuous.

\section{Results}

This section presents the results of the paper: a subsection with descriptive statistics, followed by a subsection with the econometric models.

\section{Descriptive statistics}

The objective of this section is to give an overview of the main trends in life satisfaction by age, period and cohort, controlled by selected explanatory variables. The statistical significance of the differences between groups was analyzed using ANOVA and Bonferoni ad hoc tests.

Table 1 shows the mean values for life satisfaction for age groups by period and by cohort. Life satisfaction levels by age group are higher for more recent years. Assessing the significance of the differences between periods, it is possible to verify that values for 2014 , shown in M1, were greater than those for 1991 and 1997 (m1) for the three youngest age groups. The value for 2006 was greater than those for 1991 and for 1997 for the age group 30-39 (respectively M2, $\mathrm{m} 2$ and $\mathrm{m} 2$ ). All other comparisons were non-significant. These results suggest a positive period effect for the years 2006 and 2014, for age groups between 18 and 49 years. Notice that the recent Brazilian economic crisis began in mid-2014. The fieldwork for the WVS Brazilian wave in 2014 took place in May, right before the crisis, when unemployment rates were the lowest for the month in Brazil in recent decades. This may also be explained by cohort effects, with higher levels of life satisfaction for younger cohorts, as observed for the higher values of the cohort born between 1968 and 1973 for the age groups 30-39 and 40-49. However, results for periods seemed more impressive. 
TABLE 1

Mean value for life satisfaction for age group by year and by cohort Brazil - 1991-2014

\begin{tabular}{|c|c|c|c|c|}
\hline \multirow[t]{2}{*}{ Year and cohort } & \multicolumn{4}{|c|}{ Age group } \\
\hline & $18-29$ & $30-39$ & $40-49$ & $50-59$ \\
\hline \multicolumn{5}{|c|}{ Life satisfaction for by year } \\
\hline 1991 & $3.32^{\mathrm{m} 1}$ & $3.29^{\mathrm{m} 1, \mathrm{~m} 2}$ & $3.54^{\mathrm{m} 1}$ & - \\
\hline 1997 & $3.29 \mathrm{~m} 1$ & $3.29 \mathrm{~m} 1, \mathrm{~m} 2$ & $3.43^{\mathrm{m} 1}$ & 3.62 \\
\hline 2006 & 3.63 & $3.81 \mathrm{M} 2$ & 3.78 & 3.84 \\
\hline 2014 & $3.81^{\mathrm{M} 1}$ & $3.98 \mathrm{M1}$ & $3.90^{\mathrm{M} 1}$ & 3.90 \\
\hline \multicolumn{5}{|c|}{ Life satisfaction for by cohort } \\
\hline 1968-1973 & 3.40 & $3.94^{\mathrm{M} 1, \mathrm{M} 2}$ & $4.01^{M}$ & - \\
\hline 1962-1967 & 3.30 & $3.35^{\mathrm{m} 1}$ & 3.69 & 3.66 \\
\hline 1952-1961 & - & $3.27^{\mathrm{m} 2}$ & 3.65 & 4.01 \\
\hline $1942-1951$ & - & - & $3.54^{\mathrm{m}}$ & 4.58 \\
\hline
\end{tabular}

Source: WVS, 1991, 1997, 2006, and 2014.

Table 2 shows the results for periods by cohort and by age group. The result for the oldest cohort in 2014 is not shown due to a possible selectivity of mortality rates, as discussed in the previous section. Results for different cohorts within a particular period did not differ much, and no comparisons were statistically significant. Similarly, results for different age groups within a particular period did not differ much, and no comparisons were statistically significant.

TABLE 2

Mean value for life satisfaction for year by cohort and age group Brazil - 1991-2014

\begin{tabular}{lcccc}
\hline \multicolumn{1}{c}{ Cohort and age group } & \multicolumn{3}{c}{ Year } \\
\cline { 2 - 4 } & 1991 & 1997 & $\mathbf{2 0 0 6}$ & $\mathbf{2 0 1 4}$ \\
\hline Life satisfaction by cohort & 3.33 & 3.52 & 3.94 & 4.01 \\
1968-1973 & 3.30 & 3.34 & 3.66 & 3.67 \\
1962-1967 & 3.29 & 3.33 & 3.91 & 4.04 \\
1952-1961 & 3.54 & 3.47 & 3.68 & - \\
1942-1951 & & & & 3.81 \\
\hline Life satisfaction by age group & 3.32 & 3.29 & 3.63 & 3.98 \\
18-29 & 3.29 & 3.29 & 3.81 & 3.90 \\
30-39 & 3.54 & 3.43 & 3.78 & 3.90 \\
40-49 & - & 3.62 & 3.84 & \\
$50-59$ & & & & \\
\hline
\end{tabular}

Source: WVS, 1991, 1997, 2006, and 2014.

Table 3 shows the results for cohort by year and age group. For the same cohort, as individuals grew older or time passed, life satisfaction increased significantly in two cohorts, suggesting age and/or period effects. For the cohort born between 1968 and 1973, the level of life satisfaction for 1991and for the age group 18-29 was lower than the level for more recent periods or older age groups. Similarly, for the cohort born between 1952 and 1961, the values for 1991 and 1997 and for the age group 30-39 were lower than for 2006 and 2014 or for older age groups. The other comparisons were non-significant. 
TABLE 3

Mean value for life satisfaction for cohort by year and age group

Brazil - 1991-2014

\begin{tabular}{llccc}
\hline \multicolumn{1}{c}{ Year and age group } & \multicolumn{4}{c}{ Cohort } \\
\cline { 2 - 5 } & \multicolumn{1}{c}{$1968-1973$} & $1962-1967$ & $1952-1961$ & $1942-1951$ \\
\hline Life satisfaction by year & $3.33^{\mathrm{m} 1, \mathrm{~m} 2}$ & 3.30 & $3.29^{\mathrm{m} 1, \mathrm{~m} 2}$ & 3.54 \\
1991 & 3.52 & 3.34 & $3.33^{\mathrm{m} 1, \mathrm{~m} 2}$ & 3.47 \\
1997 & $3.94^{\mathrm{M} 2}$ & 3.66 & $3.91^{\mathrm{M} 2}$ & 3.68 \\
2006 & $4.01^{\mathrm{M} 1}$ & 3.67 & $4.07^{\mathrm{M} 1}$ & - \\
2014 & & & & - \\
\hline Life satisfaction by age group & $3.40^{\mathrm{m} 1, \mathrm{~m} 2}$ & 3.30 & & - \\
$18-29$ & $3.94^{\mathrm{M} 2}$ & 3.35 & $3.27^{\mathrm{m} 1, \mathrm{~m} 2}$ & 3.52 \\
$30-39$ & $4.01^{\mathrm{M} 1}$ & 3.69 & $3.65^{\mathrm{M} 2}$ & 3.58 \\
$40-49$ & - & 3.66 & $4.01^{\mathrm{M} 1}$ & \\
$50-59$ & & & & \\
\hline
\end{tabular}

Source: WVS, 1991, 1997, 2006, and 2014.

Tables 1 to 3 presented the trends for age, period and cohort analyzed in pairs. Fosse and Winship (2019) and O־Brien and Stockard (2009) emphasized that these trends may be caused by other factors associated with the APC variables. Now we show the trends for selected explanatory variables that were found to be among the most pronounced factors correlated with life satisfaction in Brazil (CORBI; MENEZES-FILHO, 2006; ISLAM et al., 2009; RIBEIRO, 2015; RIBEIRO; MARINHO, 2017; ONUSIC; MENDES-DA-SILVA, 2015; GOLGHER, 2014a, 2014b, 2014c). For this paper, we selected the following seven variables for further analysis: health condition, marital status, importance given to family, employment status, household's financial situation, self-determination, and religiosity. All variables are positively associated with life satisfaction, with the exception of unemployment, which shows a negative correlation. Other variables, such as gender, race and schooling levels, are not considered to be among the main factors that correlate with life satisfaction in Brazil and are only used as controls in the econometric models.

Table 4 summarizes the findings for the trends for the main factors associated with life satisfaction in Brazil for each cohort. The results are based on ANOVA comparison and Bonferoni ad hoc tests. For two cohorts, life satisfaction increased with age (those born between 1952 and 1961 and between 1968 and 1973). For the other two cohorts, variations were not significant.

Health status shows a negative correlation with age, as was empirically observed here for the four cohorts. This suggests that part of the age effects observed within cohorts is due to declining health levels associated with age. In spite of the decrease in health levels observed in all cohorts as individuals grow old, the mean level for satisfaction increased for two of them and did not decrease for the others (1952-1961 and 1968-1973).

For marital status, it is interesting to notice the increase in the proportion of married individuals as people grow older in the two most recent cohorts, which is compatible with the expected pattern of change in marital status over the course of a lifetime. For older cohorts, 
the proportion of married individuals remained approximately constant or decreased. Due to these variations, regarding the association of marriage with life satisfaction, contrary to what is observed for health condition, satisfaction with life tends to increase as individuals grow older for the first two cohorts, possibly partially explaining age effects. The opposite is expected for the oldest cohort.

The proportion of individuals who think that family is very important presents a declining tendency for the two oldest cohorts (1952-1961 and 1942-1951) as they age, with non-significant results for the other two cohorts. In general, life satisfaction would decline because of this variable as individuals age beyond a threshold represented by the oldest cohorts.

Unemployment rates of individuals tend to decrease as they age. We did not observe any significant decline in any cohort as they grew older. The results for financial situation show that the two intermediate cohorts significantly improved their financial situation while aging. Thus, a positive effect on life satisfaction is found within cohorts as individuals grow older. The results for self-determination indicate an increase for two cohorts (1952-1961 and 1968-1973) as individuals aged. Thus, concerning these results, life satisfaction tended to increase as individuals aged for two out of four cohorts. The main trend for religiosity is that the variation is positive for the two youngest cohorts as individuals age, indicating an increase in life satisfaction levels due to this variable.

This table shows that satisfaction levels increased for two cohorts as they aged. Notice that two variables showed similar tendencies, self-determination and financial situation. That is, adults tend to increase their levels of self-determination and to improve their financial situations while growing older, and this might positively influence life satisfaction levels. Married status and religiosity also contributed in the same direction, but only for the two youngest cohorts. Health and the importance given to family declined for some cohorts, possibly influencing life satisfaction levels negatively as individuals aged. However, life satisfaction increased or remained constant while individuals aged despite the variations in these last two variables.

For two age groups (30-39 and 50-59), younger cohorts had higher levels of life satisfaction. Health status for cohort by year showed non-significant cohort differences. Thus, this variable does not seem to significantly explain life satisfaction differences between cohorts. Comparing cohorts at the same age, older cohorts had higher proportions of married people, indicating a more pro-marriage life perspective. Differences between cohorts at the same age indicate that part of the cohort effects are due to differences in the proportion of married individuals; however, the tendency is contrary to that observed for life satisfaction. Importance given to family showed significant results for two age groups; however, the trends were not the same. For the age group 30-39, older cohorts gave more importance to family, while the contrary was observed for the age group 50-59.

There is a trend regarding unemployment when one compares multiple cohorts at the same age group: older cohorts have lower levels of unemployment for the same year. 
That is, has this been a cross-sectional analysis, one would assume decreasing values of unemployment with age. Nonetheless, the observed is in fact a cohort effect. The negative association between unemployment and life satisfaction indicates a positive effect on life satisfaction from younger to older cohorts.

TABLE 4

Overall trends for selected variables for each synthetic cohort Brazil - 1991-2014

\begin{tabular}{|c|c|c|c|c|}
\hline \multirow[t]{2}{*}{ Select variables and year } & \multicolumn{4}{|c|}{ Cohort } \\
\hline & 1968-1973 & $1962-1967$ & 1952-1961 & 1942-1951 \\
\hline \multicolumn{5}{|l|}{ Life satisfaction } \\
\hline 1991 & $3.33^{\mathrm{m} 1, \mathrm{~m} 2}$ & 3.30 & $3.29 \mathrm{~m} 1, \mathrm{~m} 2$ & 3.54 \\
\hline 1997 & 3.52 & 3.34 & $3.33^{\mathrm{m} 1, \mathrm{~m} 2}$ & 3.47 \\
\hline 2006 & $3.94^{\mathrm{M} 2}$ & 3.66 & $3.91^{\mathrm{M} 2}$ & 3.68 \\
\hline 2014 & $4.01 \mathrm{M} 1$ & 3.67 & $4.07 \mathrm{M} 1$ & - \\
\hline \multicolumn{5}{|l|}{ Health status } \\
\hline 1991 & $1.20^{\mathrm{M} 1}$ & $1.14^{\mathrm{M} 1}$ & $0.97^{\mathrm{M} 1}$ & $0.82^{\mathrm{M} 1}$ \\
\hline 1997 & $1.11^{\mathrm{M} 2}$ & $1.07^{\mathrm{M} 2}$ & 0.91 & 0.82 \\
\hline 2006 & 1.15 & $1.03^{\mathrm{M} 3}$ & 0.94 & $0.64^{\mathrm{m} 1}$ \\
\hline 2014 & $0.95^{\mathrm{m} 1, \mathrm{~m} 2}$ & $0.83^{\mathrm{m} 1, \mathrm{~m}_{2}, \mathrm{~m}_{3}}$ & $0.75^{\mathrm{m} 1}$ & - \\
\hline \multicolumn{5}{|l|}{ Marital status } \\
\hline 1991 & $0.23^{\mathrm{m} 1, \mathrm{~m} 2, \mathrm{~m} 3}$ & $0.41^{\mathrm{m} 1, \mathrm{~m} 2}$ & 0.58 & $0.69^{\mathrm{M} 1}$ \\
\hline 1997 & $0.40 M_{3, m 2}$ & $0.58^{\mathrm{M} 2}$ & 0.61 & $0.67^{\mathrm{M} 2}$ \\
\hline 2006 & $0.54^{\mathrm{M} 2}$ & 0.47 & 0.58 & $0.60^{\mathrm{m} 1, \mathrm{~m} 2}$ \\
\hline 2014 & $0.46^{\mathrm{M} 1}$ & $0.61^{\mathrm{M} 1}$ & 0.55 & - \\
\hline \multicolumn{5}{|l|}{ Importance given to family } \\
\hline 1991 & 0.89 & 0.92 & $0.92^{\mathrm{M} 1}$ & $0.87^{\mathrm{M} 1}$ \\
\hline 1997 & 0.94 & 0.96 & $0.93^{\mathrm{M} 2}$ & $0.89^{\mathrm{M} 2}$ \\
\hline 2006 & 0.86 & 0.89 & 0.87 & $0.78^{\mathrm{m} 1, \mathrm{~m} 2}$ \\
\hline 2014 & 0.86 & 0.93 & $0.83^{\mathrm{m} 1, \mathrm{~m} 2}$ & - \\
\hline \multicolumn{5}{|l|}{ Unemployment } \\
\hline 1991 & 0.19 & 0.13 & 0.085 & 0.054 \\
\hline 1997 & 0.19 & 0.14 & 0.094 & 0.043 \\
\hline 2006 & 0.19 & 0.18 & 0.082 & 0.086 \\
\hline 2014 & 0.14 & 0.13 & 0.073 & 0.050 \\
\hline \multicolumn{5}{|l|}{ Financial situation } \\
\hline 1991 & 5.45 & 5.59 & $5.15^{\mathrm{m} 1}$ & 5.25 \\
\hline 1997 & 5.51 & $5.11^{\mathrm{m} 1, \mathrm{~m} 2}$ & $5.13^{\mathrm{m} 1}$ & 5.69 \\
\hline 2006 & 5.74 & $5.95^{\mathrm{M} 2}$ & $5.43^{\mathrm{m} 1}$ & 5.84 \\
\hline 2014 & 6.07 & $5.98^{\mathrm{M} 1}$ & $6.19 \mathrm{M} 1$ & - \\
\hline \multicolumn{5}{|l|}{ Self-determination } \\
\hline 1991 & $3.24^{\mathrm{m} 1, \mathrm{~m} 2}$ & 3.58 & $3.36^{\mathrm{m} 1, \mathrm{~m} 2}$ & 3.39 \\
\hline 1997 & 3.56 & 3.34 & $3.42^{\mathrm{m} 2}$ & 3.48 \\
\hline 2006 & $3.83^{\mathrm{M} 2}$ & 3.61 & $3.94^{\mathrm{M} 2}$ & 3.80 \\
\hline 2014 & $3.85^{\mathrm{M} 1}$ & 3.81 & $3.77^{\mathrm{M} 1}$ & - \\
\hline \multicolumn{5}{|l|}{ Religiosity } \\
\hline 1991 & $2.04^{\mathrm{m} 1, \mathrm{~m} 2}$ & $2.13^{\mathrm{m} 1, \mathrm{~m} 2, \mathrm{~m} 3}$ & 2.28 & 2.38 \\
\hline 1997 & $2.31^{\mathrm{M} 2}$ & $2.37^{\mathrm{M} 3}$ & 2.43 & 2.42 \\
\hline 2006 & $2.39^{\mathrm{M} 1}$ & $2.37^{\mathrm{M} 2}$ & 2.32 & 2.28 \\
\hline 2014 & 2.17 & $2.37^{\mathrm{M} 1}$ & 2.25 & - \\
\hline
\end{tabular}

Source: WVS, 1991, 1997, 2006, and 2014. 
For financial situation, only one age group showed significant differences. Younger cohorts were more satisfied with their financial situation. For self-determination, only one age group showed significant differences, with younger cohorts showing higher values. For religiosity, no result was significant.

TABLE 5

Overall trends for selected variables for each synthetic cohort Brazil - 1991-2014

\begin{tabular}{|c|c|c|c|c|}
\hline \multirow{2}{*}{ Select variables and cohort } & \multicolumn{4}{|c|}{ Age group } \\
\hline & $18-29$ & $30-39$ & $40-49$ & $50-59$ \\
\hline \multicolumn{5}{|l|}{ Life satisfaction } \\
\hline $1968-1973$ & 3.40 & $3.94^{\mathrm{M} 1, \mathrm{M} 2}$ & $4.01 \mathrm{M}$ & - \\
\hline 1962-1967 & 3.30 & $3.35^{\mathrm{m} 1}$ & 3.69 & 3.66 \\
\hline 1952-1961 & - & $3.27^{\mathrm{m} 2}$ & 3.65 & 4.01 \\
\hline $1942-1951$ & - & - & $3.54^{\mathrm{m}}$ & 4.58 \\
\hline \multicolumn{5}{|l|}{ Health status for } \\
\hline 1968-1973 & 1.17 & 1.15 & 0.95 & - \\
\hline 1962-1967 & 1.14 & 1.06 & 0.96 & 0.80 \\
\hline 1952-1961 & - & 0.99 & 0.82 & 0.82 \\
\hline $1942-1951$ & - & - & 0.82 & 0.75 \\
\hline \multicolumn{5}{|l|}{ Marital status } \\
\hline 1968-1973 & $0.29 \mathrm{~m}$ & 0.54 & $0.46^{\mathrm{m}}$ & - \\
\hline $1962-1967$ & $0.41^{\mathrm{M}}$ & 0.56 & $0.55^{\mathrm{m}}$ & $0.53^{\mathrm{m}}$ \\
\hline 1952-1961 & - & 0.60 & $0.58^{\mathrm{m}}$ & $0.56^{\mathrm{m}}$ \\
\hline $1942-1951$ & - & - & $0.67 \mathrm{M}$ & $0.68^{M}$ \\
\hline \multicolumn{5}{|l|}{ Importance given to family } \\
\hline 1968-1973 & 0.90 & $0.86^{\mathrm{m} 1, \mathrm{~m} 2}$ & 0.85 & - \\
\hline $1962-1967$ & 0.92 & $0.94^{\mathrm{M} 2}$ & 0.90 & $0.95^{\mathrm{M}}$ \\
\hline 1952-1961 & - & $0.93^{\mathrm{M} 1}$ & 0.90 & 0.85 \\
\hline $1942-1951$ & - & - & 0.87 & $0.84^{\mathrm{m}}$ \\
\hline \multicolumn{5}{|l|}{ Unemployment } \\
\hline 1968-1973 & $0.19 \mathrm{M}$ & $0.19 \mathrm{M} 1$ & $0.14^{\mathrm{M} 1}$ & - \\
\hline $1962-1967$ & $0.13^{m}$ & $0.15^{\mathrm{M} 2}$ & $0.14^{\mathrm{M} 2}$ & $0.17^{\mathrm{M}}$ \\
\hline 1952-1961 & - & $0.082^{\mathrm{m} 1, \mathrm{~m} 2}$ & 0.11 & $0.073^{m}$ \\
\hline $1942-1951$ & - & - & $0.055^{\mathrm{m} 1, \mathrm{~m} 2}$ & $0.048^{m}$ \\
\hline \multicolumn{5}{|l|}{ Financial situation } \\
\hline 1968-1973 & 5.47 & 5.74 & $6.07^{\mathrm{M} 1}$ & - \\
\hline 1962-1967 & 5.59 & 5.11 & $6.15^{\mathrm{M} 2}$ & 5.74 \\
\hline $1952-1961$ & - & 5.11 & $5.27^{\mathrm{m} 1, \mathrm{~m} 2}$ & 5.88 \\
\hline $1942-1951$ & - & - & $5.29^{\mathrm{m} 1, \mathrm{~m} 2}$ & 5.78 \\
\hline \multicolumn{5}{|l|}{ Self-determination } \\
\hline 1968-1973 & 4.34 & $4.83^{M}$ & 4.85 & - \\
\hline $1962-1967$ & 4.58 & 4.36 & 4.62 & 5.01 \\
\hline 1952-1961 & - & $4.36^{\mathrm{m}}$ & 4.65 & 5.02 \\
\hline $1942-1951$ & - & - & 4.41 & 4.63 \\
\hline \multicolumn{5}{|l|}{ Religiosity } \\
\hline 1968-1973 & 2.13 & 2.39 & 2.17 & - \\
\hline $1962-1967$ & 2.12 & 2.35 & 2.40 & 2.34 \\
\hline 1952-1961 & - & 2.32 & 2.35 & 2.38 \\
\hline $1942-1951$ & - & - & 2.41 & 2.34 \\
\hline
\end{tabular}

Source: WVS, 1991, 1997, 2006, and 2014. 
This section presented descriptive results of life satisfaction and selected covariates. These are further analyzed with econometric models described in the next section.

\section{Econometric models}

This section presents the results of the OLS econometric models in two tables. Table 6 presents three different models with different sets of explanatory variables. Model 1 includes only the APC variables. Model 2 incorporates some controls, and model 3 is the full model. In all of them, errors were robust to heteroscedasticity and clustered for cohorts.

We begin the presentation of the results of Table 6 with the APC variables in model 1. The coefficient for age was non-significant, while that for age squared was positive and significant. The same results were observed in model 2 . The results suggest a convex relation between age and life satisfaction, as observed by other authors. However, given that the coefficients for age were insignificant, and that in model 3 both coefficients were non-significant, the association between age and life satisfaction is better classified as nonsignificant. Any significant relationship between these variables is explained by the controls in model 3, possibly and especially due to control over life and financial situation, as both variables increased with age. All coefficients for period in all models were non-significant, indicating no net period effects. It is worth noting that the differences for period in table 1 were quite remarkable. The coefficients for the cohort born between 1962 and 1967 were negative and significant in all three models at $10 \%$ level of significance. This cohort was less satisfied with life than others, but only slightly so. For other cohorts the coefficients were non-significant, although negative. It should be noted that the coefficients for cohorts are roughly of the same magnitude, but standard deviations were greater for older cohorts. Thus, it is best to focus on the cohort born between 1986-1973, which showed a slightly higher level of life satisfaction. One possible explanation is that this cohort became 41-46 years old at the end of the period and this may have an impact on the result.

After discussing the APC variables, we focus our attention on the other variables. Differences between genders were significant in model 2, but not in model 3. Males showed greater satisfaction with life only when a smaller set of controls was included in the model. As previously discussed, results for gender are not conclusive in general (LAYARD, 2005) and different studies found different results (CORBI; MENEZES-FILHO, 2006; GRAHAM; CHATTOPADHYAY, 2013; YANG, 2008). The coefficients for race were significant and negative, indicating that non-Whites were more satisfied with life than Whites. This result is contrary to that observed for the United States (BLANCHFLOWER; OSWALD, 2004; GRAHAM, 2008), but similar to those verified by Golgher (2014a, 2014b), who also analyzed Brazil. A possible explanation is that life satisfaction is particularly defined by aspiration levels, which may be lower for non-Whites because, due to historical racism and discrimination, they hold a lower social class status. 
Studies constantly show a solid positive relationship between well-being and health (DOLAN et al., 2008; GRAHAM et al., 2011; HALLER; HADLER, 2006; HELLIWELL, 2006; RIBEIRO, 2015). We observed the same in Table 6 in both models. For marital status, in general, married people tend to be happier (BLANCHFLOWER; OSWALD, 2004; CORBI; MENEZES-FILHO, 2006; DOLAN et al., 2008; GRAHAM, 2008; HALLER; HADLER, 2006; HELLIWELL, 2006; RIBEIRO, 2015; SLUTZER; FREY, 2006). We obtained similar results for life satisfaction. Studies consistently show large negative effects of unemployment on well-being (BLANCHFLOWER; OSWALD, 2004; CORBI; MENEZES-FILHO, 2006; DOLAN et al., 2008; GRAHAM, 2008; HALLER; HADLER, 2006; HELLIWELL; PUTNAM, 2004). We observed this same trend for life satisfaction.

Now we focus the analysis on the explanatory variables incorporated in model 3. More religious individuals tend to be more satisfied with life (DOLAN et al, 2008; GRAHAM; CROWN, 2014; HALLER; HADLER, 2006; HELLIWELL, 2006; RIBEIRO, 2015). We also observed this result. Individuals who declared that they had more self-determination tend to be more satisfied with life (GOLGHER 2014a, 2014b, 2014c), also confirmed by our analysis. This same trend was expected and empirically observed for individuals in a better financial situation. Notice that perceptions of financial status might have a stronger predictive power than actual income (DOLAN et al., 2008; GRAHAM; PETTINATO, 2001; HALLER; HADLER, 2006; JOHNSON; KRUEGER, 2006; RIBEIRO, 2015). Regarding income, different authors obtained different results, but most verified a positive association between life satisfaction and income (BLANCHFLOWER; OSWALD, 2004; CORBI; MENEZESFILHO, 2006; DOLAN et al., 2008; GRAHAM, 2008; ISLAM et al., 2009; KAHNEMAN et al., 2006; RIBEIRO, 2015). We did initially include this variable in some models, and the coefficients were positive, as expected. Nonetheless, after controlling for health status, freedom and control over life, unemployment and financial situation results for income were non-significant or even negative. That is, income buys health, freedom and control over life, which can promote a better financial situation. Thus, we dropped the variable from the final models. Individuals who give more importance to family tend to be more satisfied with life (GOLGHER 2014b, 2014c). We observed non-significant coefficients. Finally, for education level, some authors found a positive association between formal education level and life satisfaction (BLANCHFLOWER; OSWALD, 2004; KAHNEMAN et al., 2006; OREOPOULOS, 2007), while others found non-significant results (GRAHAM, 2008). Layard (2005) observed that the direct effects of education were small, although the indirect effects due to income increase were noticeable. Here we mostly observed negative coefficients. One explanation is that we used a different set of controls than the studies mentioned above, including many which were slightly correlated with educational level, such as health, unemployment, financial situation, and level of control over life. Besides, life satisfaction tends to be analyzed more as a day-to-day perspective in a short horizon of analysis; this means that it is greatly influenced by the individual's level of expectations, which may be lower for less-educated Brazilians. 
TABLE 6

Results of econometric models for life satisfaction Brazil - 1991-2014

\begin{tabular}{|c|c|c|c|}
\hline Covariates & Model 1 & Model 2 & Model 3 \\
\hline \multirow[t]{2}{*}{ Age } & -0.0100 & -0.0218 & -0.0166 \\
\hline & $(0.0160)$ & $(0.0276)$ & $(0.0283)$ \\
\hline \multirow[t]{2}{*}{ Age squared } & $0.000261^{*}$ & $0.000489^{\star *}$ & 0.000257 \\
\hline & $(0.000107)$ & $(0.000147)$ & $(0.000147)$ \\
\hline 1991 & Ref. & Ref. & Ref. \\
\hline \multirow[t]{2}{*}{1997} & 0.0477 & -0.00216 & -0.188 \\
\hline & $(0.138)$ & $(0.125)$ & $(0.175)$ \\
\hline \multirow[t]{2}{*}{2006} & 0.337 & 0.215 & -0.0785 \\
\hline & $(0.315)$ & $(0.265)$ & $(0.407)$ \\
\hline \multirow[t]{2}{*}{2014} & 0.438 & 0.305 & 0.182 \\
\hline & $(0.435)$ & $(0.414)$ & $(0.468)$ \\
\hline Born 1968-1973 & Ref. & Ref. & Ref. \\
\hline \multirow[t]{2}{*}{ Born 1962-1967 } & $-0.256^{\star}$ & $-0.310^{\star}$ & $-0.274^{\star}$ \\
\hline & $(0.103)$ & $(0.104)$ & $(0.116)$ \\
\hline \multirow[t]{2}{*}{ Born 1952-1961 } & -0.178 & -0.244 & -0.108 \\
\hline & $(0.247)$ & $(0.241)$ & $(0.258)$ \\
\hline \multirow[t]{2}{*}{ Born 1942-1951 } & -0.263 & -0.393 & -0.223 \\
\hline & $(0.438)$ & $(0.412)$ & $(0.436)$ \\
\hline \multirow[t]{2}{*}{ Male } & & $0.0860^{\star \star}$ & 0.0392 \\
\hline & & $(0.0224)$ & $(0.0283)$ \\
\hline \multirow[t]{2}{*}{ White } & & $-0.209^{\star \star}$ & $-0.163^{\star \star}$ \\
\hline & & $(0.0397)$ & $(0.0470)$ \\
\hline Poor health & & Ref. & Ref. \\
\hline \multirow[t]{2}{*}{ Good health } & & $0.515^{\star \star \star}$ & $0.319^{\star \star \star}$ \\
\hline & & $(0.0498)$ & $(0.0376)$ \\
\hline \multirow[t]{2}{*}{ Very good health } & & $1.157^{\star \star \star}$ & $0.779^{\star \star \star}$ \\
\hline & & $(0.0591)$ & $(0.0837)$ \\
\hline Married & & Ref. & Ref. \\
\hline \multirow[t]{2}{*}{ Cohabitating } & & $-0.284^{\star \star}$ & $-0.326^{\star \star}$ \\
\hline & & $(0.0743)$ & $(0.0726)$ \\
\hline \multirow[t]{2}{*}{ Divorced/Separated } & & $-0.415^{\star \star}$ & $-0.396^{\star \star}$ \\
\hline & & $(0.0857)$ & $(0.112)$ \\
\hline \multirow[t]{2}{*}{ Widowed } & & -0.339 & $-0.428^{\star \star}$ \\
\hline & & $(0.156)$ & $(0.123)$ \\
\hline \multirow[t]{2}{*}{ Single } & & $-0.545^{\star \star}$ & $-0.492^{\star \star}$ \\
\hline & & $(0.135)$ & $(0.137)$ \\
\hline \multirow[t]{2}{*}{ Unemployed } & & $-0.296^{\star \star}$ & $-0.150^{\star}$ \\
\hline & & $(0.0761)$ & $(0.0502)$ \\
\hline
\end{tabular}




\begin{tabular}{|c|c|c|c|}
\hline Covariates & Model 1 & Model 2 & Model 3 \\
\hline \multirow[t]{2}{*}{ Religiosity } & & & $0.157^{\star \star}$ \\
\hline & & & $(0.0404)$ \\
\hline \multirow[t]{2}{*}{ Freedom } & & & $0.226^{\star \star \star}$ \\
\hline & & & $(0.0119)$ \\
\hline \multirow[t]{2}{*}{ Financial situation } & & & $0.208^{\star \star *}$ \\
\hline & & & $(0.0155)$ \\
\hline \multirow[t]{2}{*}{ Family } & & & 0.409 \\
\hline & & & $(0.206)$ \\
\hline Less than elementary schooling & & & Ref. \\
\hline \multirow[t]{2}{*}{ Incomplete secondary education } & & & -0.379 \\
\hline & & & $(0.214)$ \\
\hline \multirow[t]{2}{*}{ Secondary education } & & & $-0.701^{\star}$ \\
\hline & & & $(0.223)$ \\
\hline \multirow[t]{2}{*}{ Some tertiary education } & & & -0.639 ** \\
\hline & & & $(0.175)$ \\
\hline \multirow[t]{2}{*}{ University degree } & & & $-0.800^{\star *}$ \\
\hline & & & $(0.200)$ \\
\hline \multirow[t]{2}{*}{ Continuing } & $3.525^{\star \star \star}$ & $3.555^{\star \star \star}$ & $1.767^{\star}$ \\
\hline & $(0.324)$ & $(0.579)$ & $(0.683)$ \\
\hline Observations & 3,642 & 3,592 & 3,458 \\
\hline R-squared & 0.021 & 0.079 & 0.242 \\
\hline
\end{tabular}

Source: WVS, 1991, 1997, 2006, and 2014.

Note: Robust standard errors in parentheses.

${ }^{\star * *} p<0.01,{ }^{* *} p<0.05,{ }^{*} p<0.1$

Most explanatory variables presented the expected results. The APC variables showed significant results when analyzed two by two in Tables 1 to 3, but when incorporated in the models, with or without controls, their contribution was mostly non-significant.

Table 7 shows similar models to model 3 in Table 6, but we dropped the variables for cohort, as we analyzed each cohort separately. The results were similar to those in Table 6 for gender, race, health status, self-determination, and financial situation. For the sake of brevity, these are not shown. All other variables showed some differences between Table 7 and Table 6 .

As Table 6 shows, married people in general tend to be happier. We observed the same result for the first three cohorts. For the oldest cohort, those born between 1942 and 1951 , who were between 40 and 72 years old, in our analysis, the coefficients were non-significant. The results suggested, among other possibilities, that the positive association between marriage and life satisfaction is stronger when individuals are younger.

In Table 6, we observed negative effects of unemployment on life satisfaction. In Table 7, all coefficients were non-significant. Interpreting these results together with the results of the descriptive section, we can suggest that differences between cohorts in this aspect are much greater than differences within cohorts. That is, a negative coefficient for this variable in a cross-sectional analysis may represent cohort differences. 
TABLE 7

Results of econometric models for satisfaction with life by cohort

Brazil - 1991-2014

\begin{tabular}{|c|c|c|c|c|}
\hline \multirow{2}{*}{ Variables } & \multicolumn{4}{|c|}{ Cohort born in } \\
\hline & 1968-1973 & 1962-1967 & 1952-1961 & 1942-1951 \\
\hline \multirow[t]{2}{*}{ Age } & -0.0519 & 0.323 & 0.0741 & -0.140 \\
\hline & $(0.227)$ & $(0.312)$ & $(0.200)$ & $(0.260)$ \\
\hline \multirow[t]{2}{*}{ Age squared } & -0.000570 & -0.00352 & -0.000579 & 0.00162 \\
\hline & $(0.00324)$ & $(0.00377)$ & $(0.00200)$ & $(0.00224)$ \\
\hline 1991 & Ref. & Ref. & Ref. & Ref. \\
\hline \multirow[t]{2}{*}{1997} & 0.233 & -0.730 & -0.224 & $-0.580^{\star}$ \\
\hline & $(0.464)$ & $(0.572)$ & $(0.302)$ & $(0.338)$ \\
\hline \multirow[t]{2}{*}{2006} & 1.150 & -1.278 & -0.0124 & $-1.015^{\star}$ \\
\hline & $(0.858)$ & $(1.028)$ & $(0.568)$ & $(0.600)$ \\
\hline \multirow[t]{2}{*}{2014} & $2.245^{\star \star}$ & -1.182 & 0.0513 & -0.627 \\
\hline & $(1.066)$ & $(1.222)$ & $(0.667)$ & $(0.721)$ \\
\hline Married & Ref. & Ref. & Ref. & Ref. \\
\hline \multirow[t]{2}{*}{ Cohabitating } & $-0.423^{\star \star}$ & -0.115 & $-0.431^{\star \star}$ & -0.354 \\
\hline & $(0.194)$ & $(0.218)$ & $(0.193)$ & $(0.288)$ \\
\hline \multirow[t]{2}{*}{ Divorced/Separated } & $-0.673^{\star \star}$ & $-0.573^{\star \star}$ & $-0.330^{\star}$ & -0.159 \\
\hline & $(0.291)$ & $(0.228)$ & $(0.190)$ & $(0.246)$ \\
\hline \multirow[t]{2}{*}{ Widowed } & -0.0843 & $-1.014^{\star \star}$ & -0.363 & -0.304 \\
\hline & $(0.650)$ & $(0.418)$ & $(0.385)$ & $(0.238)$ \\
\hline \multirow[t]{2}{*}{ Single } & $-0.803^{\star \star \star}$ & $-0.458^{\star \star}$ & $-0.360^{\star \star}$ & 0.106 \\
\hline & (0.140) & $(0.181)$ & $(0.177)$ & $(0.273)$ \\
\hline \multirow[t]{2}{*}{ Unemployed } & -0.177 & 0.0205 & -0.141 & -0.133 \\
\hline & $(0.156)$ & $(0.212)$ & $(0.220)$ & $(0.339)$ \\
\hline \multirow[t]{2}{*}{ Religiosity } & 0.108 & 0.117 & $0.133^{\star}$ & $0.301^{\star \star \star}$ \\
\hline & $(0.0659)$ & $(0.0840)$ & $(0.0715)$ & $(0.0932)$ \\
\hline \multirow[t]{2}{*}{ Family } & 0.0459 & 0.392 & 0.263 & $0.920^{\star \star \star}$ \\
\hline & $(0.206)$ & $(0.286)$ & (0.198) & $(0.227)$ \\
\hline Less than elementary schooling & Ref. & Ref. & Ref. & Ref. \\
\hline \multirow[t]{2}{*}{ Incomplete secondary education } & 0.274 & -0.258 & $-0.502^{\star \star}$ & $-0.878^{\star \star \star}$ \\
\hline & $(0.275)$ & $(0.279)$ & $(0.220)$ & $(0.218)$ \\
\hline \multirow[t]{2}{*}{ Secondary education } & -0.0385 & $-0.743^{\star \star \star}$ & $-0.707^{\star \star \star}$ & $-1.272^{\star \star \star}$ \\
\hline & $(0.268)$ & $(0.274)$ & $(0.223)$ & $(0.262)$ \\
\hline \multirow[t]{2}{*}{ Some tertiary education } & -0.259 & -0.539 & -0.466 & $-1.169^{\star \star \star}$ \\
\hline & $(0.312)$ & $(0.329)$ & $(0.315)$ & $(0.378)$ \\
\hline \multirow[t]{2}{*}{ University degree } & -0.179 & $-0.872^{\star \star \star}$ & $-0.807^{\star \star \star}$ & $-1.223^{\star \star \star}$ \\
\hline & $(0.311)$ & $(0.318)$ & $(0.228)$ & $(0.289)$ \\
\hline \multirow[t]{2}{*}{ Continuing } & 2.857 & -5.187 & -0.169 & 3.950 \\
\hline & $(3.429)$ & $(5.729)$ & $(4.595)$ & $(7.254)$ \\
\hline Observations & 973 & 741 & 1,058 & 686 \\
\hline R-squared & 0.256 & 0.282 & 0.227 & 0.289 \\
\hline
\end{tabular}

Source: WVS, 1991, 1997, 2006, and 2014.

Note: Robust standard errors in parentheses.

*** $p<0.01,{ }^{* *} p<0.05,{ }^{*} p<0.1$.

Controls: sex, race, health condition, self-determination and financial situation. 


\section{Conclusions}

This paper discussed the factors associated with life satisfaction in Brazil using four waves of the World Values Survey from 1991 to 2014. Unlike most authors who address similar topics, we included age, period, and cohort dummies as explanatory variables. In so doing, we were able to disentangle some of the effects of these variables as related to the factors that correlate with life satisfaction.

We observed similar results as other authors for the main factors that correlate with life satisfaction: individuals who were married, employed, more religious, had better health, greater freedom/autonomy, and a better financial situation were more satisfied with life (BLANCHFLOWER; OSWALD, 2004; CORBI; MENEZES-FILHO, 2006; DOLAN et al., 2008; GRAHAM et al., 2011; HALLER; HADLER, 2006; HELLIWELL, 2006; RIBEIRO, 2015; SLUTZER; FREY, 2006). Moreover, we observed significant age, period, and cohort associations with life satisfaction when these variables were analyzed in pairs and without controls.

However, many variables among those associated with life satisfaction may explain the trends of these three variables. As suggested by Fosse and Winship (2019), other variables may explain the effects of age, period and cohort. Results for age effects were non-significant when controlling for factors associated with life satisfaction such as those cited above. For instance, as young adults age, their control over their lives increases, their financial situation improves, and they are more likely to marry, all of which are factors associated with increased well-being (BLANCHFLOWER; OSWALD, 2004; CORBI; MENEZESFILHO, 2006; DOLAN et al., 2008; GRAHAM et al., 2011; HALLER; HADLER, 2006; HELLIWELL, 2006; RIBEIRO, 2015; SLUTZER; FREY, 2006). With regard to period effects, we noticed that individuals in recent years were more satisfied with life than in the nineties. However, when controlling for covariates we found an overall non-significant result for period.

When the different cohorts were analyzed separately, the results suggested that life satisfaction might be related to the conjectural and historical factors represented by period effects. For the youngest cohort, for example, life satisfaction seems to be positively impacted by the socioeconomic boom in Brazil that occurred in the decade before the great recession which began in 2014. For the oldest cohort, individuals who had lived a greater part of their life under a military dictatorship, the slow and troublesome transition to elected civil government may have had a negative impact on life satisfaction. Cohort effects were mostly smaller and non-significant. However, differences between cohorts for marital status and unemployment were observed, both depressing life satisfaction levels of younger cohorts. 


\section{References}

ANGRIST, J.; PISCHKE, J. Mostly harmless econometrics. Princeton: Princeton University Press, 2009.

BELL, A.; JONES, K. The impossibility of separating age, period, and cohort effects. Social Science \& Medicine, v. 93, p. 163-165, 2013.

BLANCHFLOWER, D.; OSWALD, A. Well-being over time in Britain and the USA. Journal of Public Economics, v. 88, n. 7-8, p. 1359-1386, 2004.

CAVALCANTI, T.; GUIMARÃES, J.; NOGUEIRA, J. Is Brazil the land of happiness? A comparative study using a sample with economics students from UFPE and Purdue. Brazilian Review of Econometrics, v. 29, n. 1, p.17-35, 2009.

CLARK, A.; LELKES, O. Deliver us from evil: religion as insurance. Paris: PSE, 2005.

CORBI, R.; MENEZES-FILHO, N. Os determinantes empíricos da felicidade no Brasil. Revista de Economia Política, v. 26, n. 4, p. 18-36, 2006.

COUTINHO, R.; GOLGHER, A. The changing landscape of religious affiliation in Brazil between 1980 and 2010: age, period, and cohort perspective. Revista Brasileira de Estudos de População, v. 31, n. 1, p. 73-98, 2014.

DEATON, A. Panel data from time series of cross-sections. Journal of Econometrics, v. 30, n. 1, p. 109-126, Oct. 1985.

DEVEREUX, P. T. Small-sample bias in synthetic cohort models of labor supply. Journal of Applied Econometrics, v. 22, n. 4, p. 839-848, 2007.

DOLAN, P.; PEASGOOD, T.; WHITE, M. Do we really know what makes us happy? A review of the economic literature on the factors associated with subjective well-being. Journal of Economic Psychology, v.29, p. 94-122, 2008.

EASTERLIN, R. A. Does economic growth improve the human lot? Some empirical evidence. In: DAVID, R.; REDER, R. (ed.). Nations and households in economic growth: essays in honor of Moses Abramovitz. New York: Academic Press, 1974. p. 89-125.

FOSSE, E.; WINSHIP, C. Analyzing age-period-cohort data: a review and critique. Annual Review of Sociology, v. 45, p. 467-92, 2019.

FREY, B. Happiness - A revolution in economics. Cambridge: The MIT Press, 2008.

FUKUDA, K. A happiness study using age-period-cohort framework. Journal of Happiness Studies, v. 14, n. 1, p. 135-153, 2013.

GLENN, N. D. Distinguishing age, period, and cohort effects. In: MORTIMER, J. T.; SHANAHAN, M. J. (ed.). Handbook of the life course. Springer, 2003.

GOLGHER, A. An introduction to the determinants of happiness in Brazil. Belo Horizonte: Cedeplar/UFMG, 2014a. (Texto para discussão, n. 508).

GOLGHER, A. The influence of attitudes and beliefs on the determinants of happiness in Brazil. Belo Horizonte: Cedeplar/UFMG, 2014b. (Texto para discussão, n. 509).

GOLGHER, A. An overview of the determinants of happiness in Brazil in 2006. Belo Horizonte: Cedeplar/UFMG, 2014c. (Texto para discussão, n. 510).

GRAHAM, C. Happiness and health: lessons and questions for public policy. Health Affairs, v. 27, n. 1, p. 72-87, January-February 2008. 
GRAHAM, C.; CHATTOPADHYAY, S. Gender and well-being around the world. International Journal of Happiness and Development, v. 1, n. 2, p. 212-236, January 2013.

GRAHAM, C.; CROWN, S. Religion and well-being around the world: social purpose, social time, or social insurance? International Journal of Well-Being, v. 4, n. 1, p. 1-27, January 2014.

GRAHAM, C.; HIGUERA, L.; LORA, E. Which health conditions cause the most unhappiness? Health Economics, v. 20, n. 12, p. 1431-1447, November 2011.

GRAHAM, C.; PETTINATO, S. Happiness, markets and democracy: Latin America in comparative perspective. Journal of Happiness Studies, v. 2, n. 3, p. 237-268, 2001.

GUIMARÃES, R.; RIOS-NETO, E. Comparação entre metodologias de idade-período-coorte para o estudo de uma medida da progressão escolar no Brasil. Revista Brasileira de Estudos de População, v. 28, n. 2, p. 349-367, 2011.

HALLER, M.; HADLER, M. How social relations and structures can produce happiness and unhappiness: an international comparative analysis. Social Indicators Research, v. 75, n. 2, p. 169-216, 2006.

HELLIWELL, J. Well-being, social capital and public policy: what's new? Economic Journal, v. 116, n. 510, p. C34-C45, 2006.

HELLIWELL, J.; LAYARD, R.; SACHS, J. World happiness report 2016, update (vol. I). New York: Sustainable Development Solutions Network, 2016.

HELLIWELL, J.; PUTNAM, R. The social context of well-being. Philosophical Transactions of the Royal Society London, v. 359, p. 1435-1446, 2004.

ISLAM, G.; WILLS-HERRERA, E.; HAMILTON, M. Objective and subjective indicators of happiness in Brazil: the mediating role of social class. Journal of Social Psychology, v. 149, n. 2, p. 267272, 2009.

JOHNSON, W.; KRUEGER, R. How money buys happiness: genetic and environmental processes linking finances and life satisfaction. Journal of Personality and Social Psychology, v. 90, n. 4, p. 680-691, 2006.

JORM, A.; RYAN, S. Cross-national and historical differences in subjective well-being. International Journal of Epidemiology, v. 43, n. 2, p. 330-340, 2004.

KAHNEMAN, D.; KRUEGER, A.; SCHKADE, D.; SCHWARZ, N.; STONE, A. Would you be happier if you were richer? A focusing illusion. Science, v. 312, n. 5782, p.1908-1910, 2006.

KUPPER, L.; JANIS, J.; KARMOUS, A.; GREENBERG, B. Statistical age-period-cohort analysis: a review and critique. Journal of Chronic Diseases, v. 38, n.10, p. 811-830, 1985.

LAYARD, R. Happiness - Lessons from a new science. New York: Peguin Books, 2005.

LEME, M.; WAJNMAN, S. Tendências de coorte nos diferenciais de rendimentos por sexo. In: HENRIQUES, R. (ed.). Desigualdade e pobreza no Brasil. Rio de Janeiro: Ipea, 2000.

LIU, B.; FLOUD, S.; PIRIE, K.; GREEN, J.; PETO, R.; BERAL, V. Does happiness itself directly affect mortality? The prospective UK Million Women Study. Lancet, v. 387, n. 10021, p. 874-881, 2016.

MASON, W.; SMITH, H. Age-period-cohort analysis and the study of deaths from pulmonary tuberculosis. In: MASON, W.; FIENBERG, S. (ed.). Cohort analysis in social research. New York: Springer-Verlag, 1985. p. 151-228.

MEDVEDEV, O.; LANDHUIS, C. Exploring constructs of well-being, happiness and quality of life. PeerJ, 6:e4903, 2018. 
NEMATI, S.; MARALANI, F. The relationship between life satisfaction and happiness: the mediating role of resiliency. International Journal of Psychological Studies, v. 8, n. 3, p. 194-201, 2016.

NG, Y. Happiness, life satisfaction, or subjective well-being? A measurement and moral philosophical perspective, 2015. Available at: 〈https://www.ntu.edu.sg/home/ykng/ Happiness,LS,\%20SWB-2015.pdf〉.

O'BRIEN, R.; STOCKARD, J. Can cohort replacement explain changes in the relationship between age and homicide offending? Journal of Quantitative Criminology, v. 25, n. 1, p. 79-101, 2009.

ONUSIC, L.; MENDES-DA-SILVA, W. Orgulho de ser brasileiro impacta o nível de felicidade? Revista de Administração Contemporânea, v. 19, n. 6, p. 712-731, 2015.

OREOPOULOS, P. Do dropouts drop out too soon? Wealth, health and happiness from compulsory schooling. Journal of Public Economics, v. 91, n. 11-12, p. 2213-2229, 2007.

RIBEIRO, C. Renda, relações sociais e felicidade no Brasil. Dados - Revista de Ciências Sociais, V. 58, n. 1, p. 37-78, 2015.

SHIELDS, M.; PRICE, S. Exploring the economic and social determinants of psychological wellbeing and perceived social support in England. Journal of the Royal Statistical Society, v. 168, n. 3, p. 513-537, 2005.

SLUTZER, A.; FREY, B. Does marriage make happy, or do happy people get married? Journal of Socio-Economics, v. 35, n. 2, p. 326-347, 2006.

SMITH, H. Response: cohort analysis redux. Sociological Methodology, v. 34, n. 1, p. 111-119, 2004.

SOUZA, M.; VASCONCELOS, A.; CRUZ, O. Trends in lung cancer mortality in Brazil from the $1980 \mathrm{~s}$ into the early 21st century: age-period-cohort analysis. Cadernos de Saúde Pública, v. 28, n. 1, p. 21-30, 2012.

VERBEEK, M.; NIJMAN, T. Can cohort data be treated as genuine panel data? Empirical Economics, V. 17, n. 1, p. 9-23, 1992.

YANG, Y. Social inequalities in happiness in the United States, 1972 to 2004: an age-period-cohort analysis. American Sociological Review, v. 73, n. 2, p. 204-226, 2008.

YANG, Y. Aging, cohorts, and methods. In: BINSTOCK, R.; GEORGE, L. (ed.). The handbook of aging and the social sciences. London: Elsevier, 2011. p. 17-30.

YANG, Y.; FU, W.; LAND, K. A methodological comparison of age-period-cohort models: intrinsic estimator and conventional generalized linear models. Sociological Methodology, v. 34, p. 75-110, 2004.

YANG, Y.; SCHULHOFER-WOHL, S.; FU, W.; LAND, K. The intrinsic estimator for age-period-cohort analysis: what is it and how to use it. American Journal of Sociology, v. 113, n. 6, p. 1697-1736, 2008.

WINKELMANN, L.; WINKELMANN, R. Why are the unemployed so unhappy? Evidence from panel data. Economica, v. 65, n. 257, p. 1-15, 1998.

\section{About the authors}

André Braz Golgher has a Ph.D. in Demography from Universidade Federal de Minas Gerais (UFMG). He is an associate professor at the Economics Department in UFMG.

Raquel Zanatta Coutinho has a Ph.D. in Sociology from University of North Carolina at Chapel Hill (UNC-CH). She is an assistant professor at the Demography Department in UFMG. 


\title{
Contact address
}

\author{
André Braz Golgher \\ Rua Cristina 1092/302, Santo Antônio \\ 30330-228 - Belo Horizonte-MG, Brazil \\ Raquel Zanatta Coutinho \\ Rua Cristina 1092/302, Santo Antônio \\ 30330-228 - Belo Horizonte-MG, Brazil
}

\section{Resumo}

Satisfação com a vida no Brasil: uma exploração de correlatos teóricos e variações de idade, período e coorte usando o World Values Survey (1991-2014)

Esse artigo analisa fatores relacionados à satisfação com a vida no Brasil, utilizando as quatro ondas da pesquisa World Values Survey (1991 até 2014). Foram confirmados alguns resultados já descritos na literatura, tais como pessoas casadas, mais saudáveis, empregadas, mais religiosas e que tinham maior controle sobre a própria vida e melhor condição financeira se consideravam mais satisfeitas com a vida. Quanto às variáveis idade e coorte, os resultados foram não significativos quando analisados com fatores correlacionados com a satisfação com a vida. Quando diferentes coortes foram analisadas separadamente, os resultados sugeriram que a satisfação com a vida se mostrou relacionada com fatores históricos e conjunturais representados pelos efeitos de períodos.

Palavras-chave: Satisfação com a vida. Brasil. World Values Survey.

\section{Resumen}

Satisfacción vital en Brasil: una exploración de correlatos teoréticos y variaciones de edad, período y cohorte usando la World Values Survey (1991-2014)

Ese artículo analizó factores asociados con la satisfacción con la vida en Brasil utilizando cuatro pesquisas de la World Values Survey desde 1991 hasta 2014. Fueron confirmados algunos resultados ya descritos en la literatura, como casados, personas más saludables, empleadas o más religiosos, que tenían un mayor control de sus propias vidas y que las de mejor condición financiera se consideraban más satisfechas con la vida. Con relación a las variables edad y cohorte, los efectos generales fueron no significativos al ser analizadas junto con otros aspectos correlacionados con la satisfacción con la vida. Cuando fueron analizadas diferentes cohortes separadamente, los resultados sugirieron que la satisfacción con la vida estaba relacionada con factores históricos y coyunturales representados por los efectos de los períodos.

Palabras clave: Satisfacción con la vida. Brasil. World Values Survey.

Received for publication in 04/09/2019

Approved for publication in 11/11/2019 